\title{
Preliminary Study on Air Quality of Srinagar, (J\&K), India
}

\author{
Mehvish Sheikh ${ }^{1} \&$ Ishtiyaq Ahmed Najar ${ }^{2}$ \\ ${ }^{1}$ P. G. Department of Environmental Sciences, S. P. College, India \\ ${ }^{2}$ Department of Environmental Sciences, G. D. College, Ganderbal, India \\ Correspondence: Ishtiyaq Ahmed Najar, G. D. College, Ganderbal, Kashmir (J\&K) 191201, India. Tel: \\ 91-97-9695-7773.
}

Received: May 21, 2018

Accepted: June 7, 2018

Online Published: June 17, 2018

doi:10.20849/jess.v1i1.421

URL: https://doi.org/10.20849/jess.v1i1.421

\begin{abstract}
The present work was carried out to study the air quality of Srinagar city and the samples were collected from five different sites which includes commercial area (site-I), industrial area (site-II), residential area (site-III), ecologically sensitive site (site-IV) and sensitive area (site-V). During the study samples were taken on monthly basis and were analyzed for nitrogen dioxide $\left(\mathrm{NO}_{2}\right)$, sulphur dioxide $\left(\mathrm{SO}_{2}\right)$ and repairable particulate matter $\left(\mathrm{PM}_{10}\right)$. Significant variation was recorded within and among the sites in $\mathrm{NO}_{2}\left(\mathrm{~F}_{3}=3.82 ; \mathrm{F}_{4}=115, \mathrm{P}<0.05\right)$, whereas among the sites in $\mathrm{SO}_{2}$ and $\mathrm{PM}_{10}\left(\mathrm{~F}_{4}=167, \mathrm{P}<0.05\right)$ and $\left(\mathrm{F}_{4}=72.55, \mathrm{P}<0.05\right)$ respectively. The study revealed higher concentration of $\mathrm{NO}_{2}$ at Lal chowk which is commercial area and vehicular emission could be the one of the reason for higher value of $\mathrm{NO}_{2} . \mathrm{SO}_{2}$ exhibited high concentration at industrial area and could be attributed to burning of fossil fuels in industries and use of generator sets. $\mathrm{PM}_{10}$ was also found higher in industrial area due to presence of cement industries in addition to burning of coal as fuel. The overall concentration of $\mathrm{NO}_{2}$ and $\mathrm{SO}_{2}$ were found within the permissible limits for all sites as per National Ambient Air Quality Standards (NAAQS) except for $\mathrm{PM}_{10}$ at site-I and site-II. The overall air quality index of site-I and site-II falls within "Moderate" category and for site-III, IV and V falls within "Good" category.
\end{abstract}

Keywords: air pollution, air quality, sites, srinagar

\section{Introduction}

Air is one of the vital components of environment that human beings have to live in throughout their life and affect the quality of life. The advent of technological and scientific innovations in various fields and diverse anthropogenic activities have put extra load on the atmosphere by way of releasing air pollutant like suspended particulate matter (SPM), respirable suspended particulate matter (RSPM), sulphur dioxide $\left(\mathrm{SO}_{2}\right)$, oxides of nitrogen $\left(\mathrm{NO}_{\mathrm{x}}\right)$, carbon monoxide $(\mathrm{CO})$, unburned hydrocarbon $(\mathrm{HC})$, hydrogen fluoride $(\mathrm{HF})$ and other organic as well as inorganic pollutants including trace metals.

Urban air quality is one of the most serious issues, receiving attention in developing as well as developed countries (Dadhich et al., 2017). In India, pollution has become a great topic of debate at all levels and especially the air pollution because of enhanced anthropogenic activities such as burning fossil fuels (coal and petroleum) and vehicle emission due to its adverse effect on health. Among the different harmful chemical compounds, the pollutants of concern are carbon monoxide $(\mathrm{CO})$, nitrogen oxides $\left(\mathrm{NO}_{\mathrm{x}}\right)$, sulphur dioxide $\left(\mathrm{SO}_{2}\right)$ and suspended particulate matter, including lead from gasoline. Nitrogen dioxide $\left(\mathrm{NO}_{2}\right)$, sulphur dioxide $\left(\mathrm{SO}_{2}\right)$ and suspended particulate matter (SPM) are regarded as prime air pollutants in India (Rai \& Chutia, 2014; Kishore \& Deswal, 2017). In many Indian cities, the levels of particulate pollutants in the ambient air have been found to be above the permissible limit (Meenakshi \& Saseetharan, 2003). $\mathrm{SO}_{2}$ is a prime pollutant which is released directly to the atmosphere from domestic and industrial processes, particularly those using petroleum and coal combustion (Wellburn, 1998; Emberson et al., 2001). Coal-fired power plants and vehicles are the largest sources of $\mathrm{NO}_{\mathrm{x}}$ and are produced in high temperature combustion processes (Memon, 2000). SPM are finely divided solids or liquids that are dispersed throughout the air and are produced from combustion processes, domestic and industrial activities, as well from natural sources such as volcanoes, dust and forest fires (Emberson et al., 2001). According to international agency for research on cancer (2013), outdoor air pollution is carcinogenic to humans, with the particulate matter (PM) component of air pollution most closely associated with increased cancer incidence, especially cancer of the lung (Loomis et al., 2013). Other pollutants, such as nitrogen oxides $\left(\mathrm{NO}_{\mathrm{x}}\right)$, 
sulphur dioxide $\left(\mathrm{SO}_{2}\right)$ and ammonia $\left(\mathrm{NH}_{3}\right)$ contribute to the acidification of soil, lakes and rivers, causing the loss of animal and plant life, in addition to the adverse effects on human health.

An air quality index (AQI) is one of the important tool available for analyzing and interpreting air quality status uniformly (Swami \& Tyagi, 1999; Taieb \& Brahim, 2013). An air quality index is defined as an overall scheme that transforms the weighed values of individual air pollution related parameters into a single number or set of numbers (Ott, 1978). There have not been significant efforts to develop and use AQI in India, primarily due to the fact that a modest air quality monitoring programme was started only in 1984 and public awareness about air pollution was almost non-existent. The challenge of communicating with the people in a comprehensible manner has two dimensions as translate the complex scientific and medical information into simple and precise knowledge and to communicate with the citizens in the historical, current and futuristic sense. Addressing these challenges and thus developing an efficient and comprehensible AQI scale is required for citizens and policy makers to make decisions to prevent and minimize air pollution exposure and ailments induced from the exposure. Briefly, an AQI is useful for general public to interpret air quality in a simplified way, a politician to invoke quick actions, a decision maker to know the trend of events and to chalk out corrective pollution control strategies, a government official to study the impact of regulatory actions and a scientist who engages in scientific research using air quality data.

\section{Materials and Methods}

\subsection{Study Area}

The Valley of Kashmir is a lacustrine basin of the intermountain depression existing between the Lesser and Greater Himalayas characterized by numerous aquatic ecosystems of great ecological and economic importance (Najar \& Khan, 2012; Ishtiyaq et al., 2017). It is located within the geographical coordinates of $33.7782^{\circ} \mathrm{N}$, $76.5762^{\circ} \mathrm{E}$ and lies in the temperate zone, characterized by wet and cold winter and relatively dry and moderate hot summer. The hottest months are July and August, when the maximum temperature rises above $30^{\circ} \mathrm{C}$ (Najar \& Khan, 2011). September has cooler nights and the severe winter sets in about the middle of December (Najar \& Khan, 2014). The coldest month is January, with temperature falling below freezing point (Najar \& Khan, 2013). The winters vary from year to year; some are severe with very heavy snowfall, while others are mild with moderate snowfall (Najar et al., 2015).

Srinagar is the summer capital of Jammu and Kashmir. It is located within the Geographical Coordinates of $34^{\circ} 5^{\prime} 24^{\prime \prime} \mathrm{N} 74^{\circ} 47^{\prime} 24^{\prime \prime} \mathrm{E}$, with the mean elevation of $1585 \mathrm{~m}$. The area of Srinagar has increased from $83 \mathrm{~km}^{2}$ in 1971 to $103.81 \mathrm{~km}^{2}$ in 1987 . It further expanded to $117 \mathrm{~km}^{2}$ in the later years. With further expansion of the city the area increased to $300 \mathrm{~km}^{2}$. The master plan (2000-2021) has termed the Srinagar city as Greater Srinagar and placed the area measurement to $416.25 \mathrm{~km}^{2}$.

\subsection{Study Sites}

For the study of air quality of Srinagar 5 sites were selected across the study area with different characteristics. The details about the sites are given in Table 1 .

Table 1. Description of the study sites

\begin{tabular}{lcccc}
\hline Site & Site location & Geographical coordinates & Elevation (masl) & Nature of site \\
\hline Site-I & Lal chowk & $34^{\circ} 09^{\prime} 00^{\prime \prime} \mathrm{N} 74^{\circ} 79^{\prime} 00^{\prime \prime} \mathrm{E}$ & 1563 & Commercial area \\
Site-II & Khanmoh & $34^{\circ} 03^{\prime} 27^{\prime \prime} \mathrm{N} 74^{\circ} 57^{\prime} 80^{\prime \prime} \mathrm{E}$ & 1638 & Industrial area \\
Site-III & Rainawari & $34^{\circ} 05^{\prime} 52^{\prime \prime} \mathrm{N} 74^{\circ} 49^{\prime} 18^{\prime \prime} \mathrm{E}$ & 1575 & Residential area \\
Site-IV & Nehru Park & $34^{\circ} 05^{\prime} 21^{\prime \prime} \mathrm{N} 74^{\circ} 50^{\prime} 43^{\prime \prime} \mathrm{E}$ & 1565 & Ecologically sensitive \\
Site-V & SMHS & $34^{\circ} 05^{\prime} 09^{\prime \prime} \mathrm{N} 74^{\circ} 47^{\prime} 49^{\prime \prime} \mathrm{E}$ & 1586.4 & Sensitive \\
\hline
\end{tabular}

\subsection{Air Sampling}

Air sampling was carried out by using air sampler of Envirotech. At each site samples were collected on monthly basis, by keeping the sampler at a height of 2 meter above ground level. $\mathrm{SO}_{2}$ was determined by using Modified West and Gaeke method (1956). The determination of $\mathrm{NO}_{2}$ is carried out by using Jacob and Hochheiser method (1958). $\mathrm{PM}_{10}$ was determined by Gravimetric method. Air quality index was calculated using IND-AQI by the following formula: 
$I_{p}=\left[I_{H I}-I_{L O} / B_{P_{H I}}-B P_{L O}\left(C_{P}-B_{L O}\right)\right]+I_{L O}$

Where:

$I_{\mathrm{P}}=$ Index for pollutant " $p$ ".

$\mathrm{B}_{\mathrm{HI}}=$ Break point concentration greater or equal to given concentration.

$\mathrm{B}_{\mathrm{LO}}=$ Break point concentration smaller or equal to given concentration.

$\mathrm{I}_{\mathrm{HI}}=\mathrm{AQI}$ value corresponding to $\mathrm{BHI}$.

$\mathrm{I}_{\mathrm{LO}}=\mathrm{AQI}$ value corresponding to BLO.

$\mathrm{C}_{\mathrm{P}}=$ Pollutant concentration.

\section{Results and Discussion}

\subsection{Nitrogen Dioxide $\left(\mathrm{NO}_{2}\right)$}

The concentration of $\mathrm{NO}_{2}$ recorded at different sites and during different months is given Figure 1. $\mathrm{NO}_{2}$ showed significant variation within $\left(\mathrm{F}_{3}=3.82, \mathrm{P}<0.05\right)$ and among $\left(\mathrm{F}_{4}=115, \mathrm{P}<0.05\right)$ the sites. At site-I, the concentration of $\mathrm{NO}_{2}$ varied from of $17.97 \mu \mathrm{g} / \mathrm{m}^{3}$ during November to maximum of $19.01 \mu \mathrm{g} / \mathrm{m}^{3}$ during January and at site-II, $\mathrm{NO}_{2}$ ranged from minimum value of $16.69 \mu \mathrm{g} / \mathrm{m}^{3}$ in the month of October to maximum $17.90 \mu \mathrm{g} / \mathrm{m}^{3}$ in the month of January. The site-III exhibited a mean value of $12.00 \mu \mathrm{g} / \mathrm{m}^{3}$ during October to maximum of $15.80 \mu \mathrm{g} / \mathrm{m}^{3}$ during January. At site-IV, $\mathrm{NO}_{2}$ ranged from minimum of $9.97 \mu \mathrm{g} / \mathrm{m}^{3}$ during October to maximum of $11.00 \mu \mathrm{g} / \mathrm{m}^{3}$ during January whereas at site- $\mathrm{V}$, the minimum and maximum concentrations were found to be $9.92 \mu \mathrm{g} / \mathrm{m}^{3}$ during December and $11.10 \mu \mathrm{g} / \mathrm{m}^{3}$ during January respectively. The mean value recorded at the different sites is given in (Figure 2) and was $10.35 \pm 0.26 \mu \mathrm{g} / \mathrm{m}^{3}$ (SMHS), $10.46 \pm 0.23 \mu \mathrm{g} / \mathrm{m}^{3}$ (Nehru Park), $14.25 \pm 0.88 \mu \mathrm{g} / \mathrm{m}^{3}$ (Rainawari), $17.17 \pm 0.25 \mu \mathrm{g} / \mathrm{m}^{3}$ (Khanmoh) and $17.17 \pm 0.24 \mu \mathrm{g} / \mathrm{m}^{3}$ (Lal chowk). In the present study, $\mathrm{NO}_{2}$ ranged from $9.92 \mu \mathrm{g} / \mathrm{m}^{3}$ and $19.01 \mu \mathrm{g} / \mathrm{m}^{3}$. Banerjee and Srivastava (2010) also reported the values of $\mathrm{NO}_{2}$ around this range $\left(21.7 \mu \mathrm{g} / \mathrm{m}^{3}\right)$. The study of Sarangi and Mishra (1997) also showed the value of $\mathrm{NO}_{2}$ ranging from $4.39 \mu / \mathrm{m}^{3}$ to $16.89 \mu \mathrm{g} / \mathrm{m}^{3}$. Site-I represents the commercial area and the maximum value of $\mathrm{NO}_{2}$ $\left(19.01 \mu \mathrm{g} / \mathrm{m}^{3}\right)$ was recorded. The reason attributed is vehicular emission in the area and the area being highly urbanized.
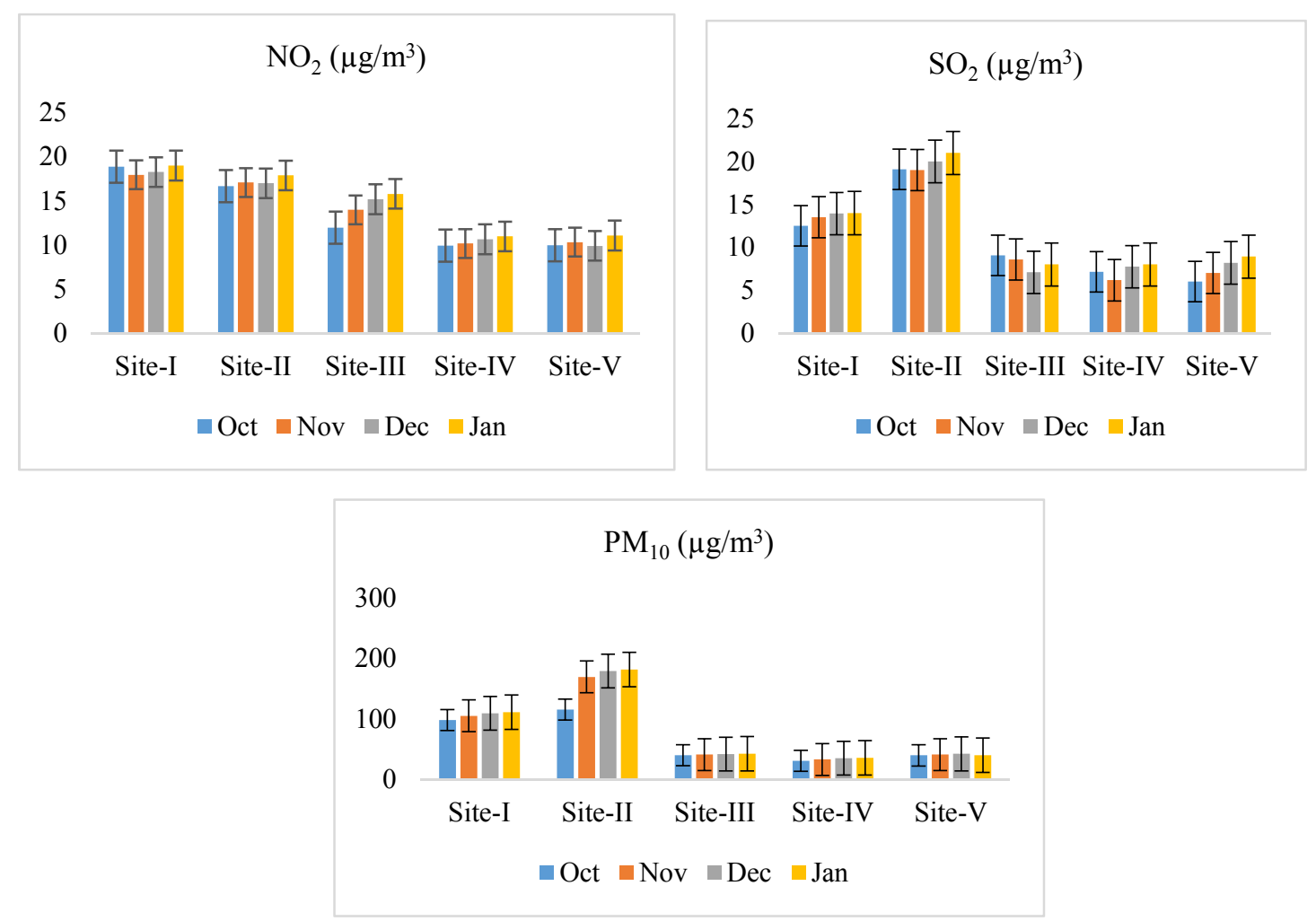

Figure 1. Monthly variation in $\mathrm{NO}_{2}, \mathrm{SO}_{2}$ and $\mathrm{PM}_{10}$ at different sites 


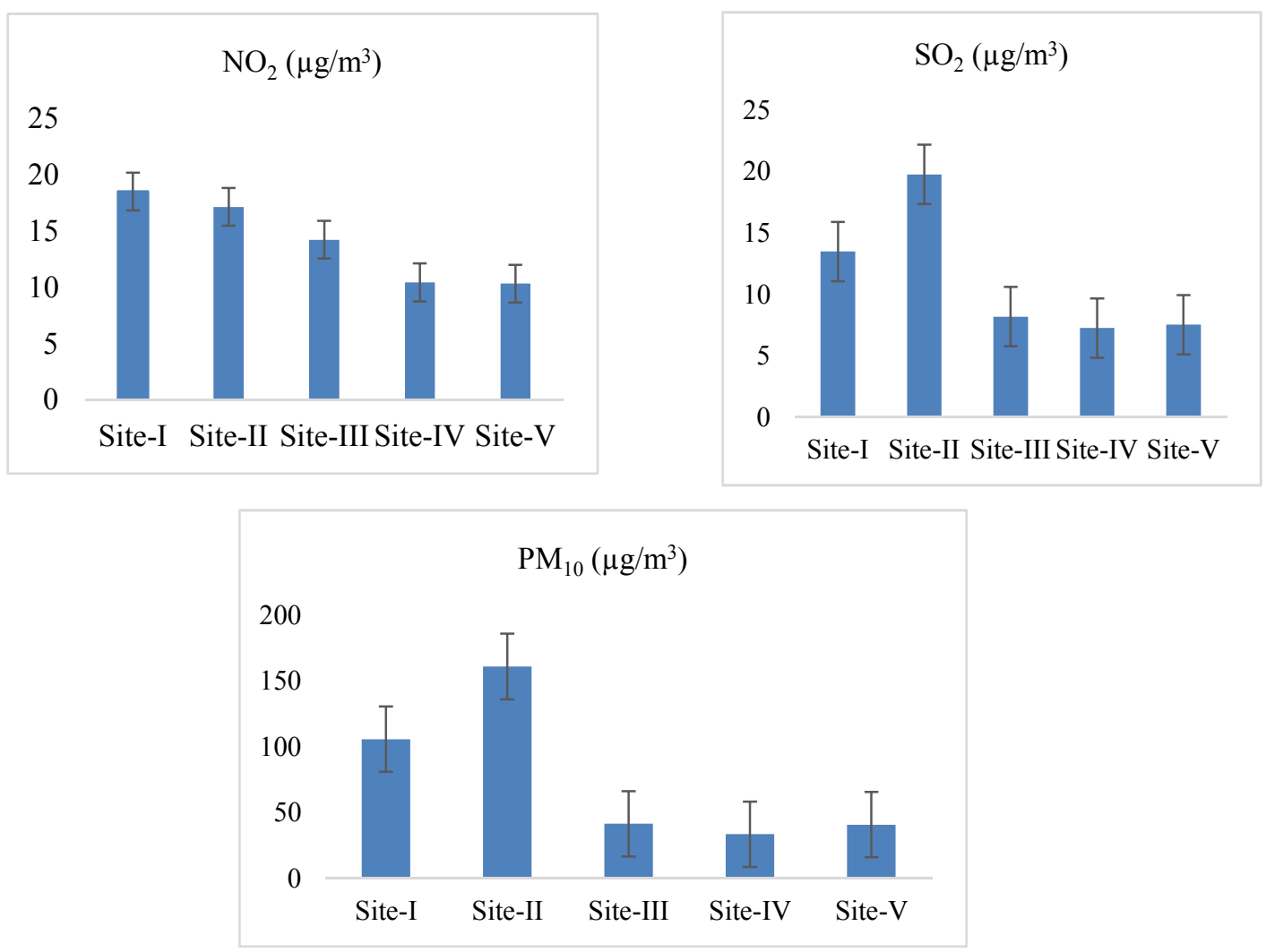

Figure 2. Mean value of $\mathrm{NO}_{2}, \mathrm{SO}_{2}$ and $\mathrm{PM}_{10}$ at different sites

The study of Hussan et al. (2013) reported that vehicular exhaust is the main cause of $\mathrm{NO}_{2}$. Aneja et al. (2001) also reported the mobile sources as the predominant contributor of $\mathrm{NO}_{2}$. According to Panda and Panda (2012) the main factor responsible for the higher level of $\mathrm{NO}_{2}$ is transportation. Mandal (2000) revealed in its study that $\mathrm{NO}_{2}$ is found higher in near highly urbanized areas. The concentration is higher in the areas where tree density is low according to the study of Grundström and Pleijel (2014).

The minimum values are recorded in SMHS Hospital being a sensitive area. The low values are due to the reason that the vehicular density in the hospital is very low and no industrial setup is located in the vicinity of the area. The study of Sharma and Raina (2015) also reported that $\mathrm{NO}_{2}$ exhibited its low values at residential area as compared to commercial and traffic crossing.

During the study, the higher values of $\mathrm{NO}_{2}$ were recorded during the winter months (January) as compared to other months and might be attributed to the fact that winter months have comparatively calm weather conditions, facilitating more stability to atmosphere and thus slow dispersion of pollutants resulting in higher concentration of pollutants in ambient air. The study of Lakshmanarao and Satish (2014) also reported maximum values during winter season. Panda and Panda (2012) also record relatively higher levels of $\mathrm{NO}_{2}$ during winter in comparison to summer and monsoon.

\subsection{Sulphur Dioxide $\left(\mathrm{SO}_{2}\right)$}

The concentration of $\mathrm{SO}_{2}$ recorded at different sites and during different months is given Figure $1 . \mathrm{SO}_{2}$ exhibited significant variation among $\left(\mathrm{F}_{4}=167, \mathrm{P}<0.05\right)$ the sites whereas no significant variation was recorded within $\left(\mathrm{F}_{3}=2.29, \mathrm{P}<0.05\right)$ the sites. At site-I, the minimum and maximum concentration of $\mathrm{SO}_{2}$ were found to be $12.51 \mu \mathrm{g} / \mathrm{m}^{3}$ in the month of October and $14.00 \mu \mathrm{g} / \mathrm{m}^{3}$ in the month of January respectively. At site-II, mean value was found to be varied from $19.00 \mu \mathrm{g} / \mathrm{m}^{3}$ during November and to $21.00 \mu / \mathrm{m}^{3}$ during January. At site-III, $\mathrm{SO}_{2}$ exhibited concentration from minimum of $7.09 \mu \mathrm{g} / \mathrm{m}^{3}$ during December to maximum of $9.06 \mu \mathrm{g} / \mathrm{m}^{3}$ during October and at site-IV, $\mathrm{SO}_{2}$ ranged from $6.17 \mu \mathrm{g} / \mathrm{m}^{3}$ (minimum) during November to $8.00 \mu \mathrm{g} / \mathrm{m}^{3}$ (maximum) during January. The concentration of $\mathrm{SO}_{2}$ varied from minimum of $6.00 \mu \mathrm{g} / \mathrm{m}^{3}$ in the month of October to maximum of $8.92 \mu \mathrm{g} / \mathrm{m}^{3}$ in the month of January at site-V. The mean value (Figure 2) recorded at sites was $19.99 \pm 0.46$ (Khanmoh), $13.49 \pm 0.34$ (Lalchowk), $8.19 \pm 0.42$ (Rainawari), $7.53 \pm 0.06$, (SMHS) and 7.26 \pm 0.40 (Nehru park). 
The recorded concentration of $\mathrm{SO}_{2}$ varies from $6.00 \mu \mathrm{g} / \mathrm{m}^{3}$ to $21.00 \mu \mathrm{g} / \mathrm{m}^{3}$ during the study. Sarangi and Mishra (1997) and Saksena et al. (2003) also reported the values of $\mathrm{SO}_{2}$ ranging from $4.62 \mu \mathrm{g} / \mathrm{m}^{3}$ to $25.74 \mu \mathrm{g} / \mathrm{m}^{3}$ and $8.4 \mu \mathrm{g} / \mathrm{m}^{3}$ to $51.2 \mu \mathrm{g} / \mathrm{m}^{3}$ respectively.

The maximum concentration of $\mathrm{SO}_{2}\left(21.00 \mu \mathrm{g} / \mathrm{m}^{3}\right)$ was found at Site-II and could be attributed to emission from different industrial units as the site represents the industrial area. The maximum concentration is due to the fact that the area is highly industrialized and burning of fuel emissions from industries is prominent resulting in increase in concentration of $\mathrm{SO}_{2}$. Further the use of generator sets, poorly maintained roads, frequent traffic jams and slow speed of vehicles also contribute to the high levels. The study of Banerjee and Srivastava (2003) also revealed the value of $\mathrm{SO}_{2}$ to be $21.1 \mu \mathrm{g} / \mathrm{m}^{3}$ which collaborates with the present study. Barman et al. (2010) also reported the value of $\mathrm{SO}_{2}$ within the range of $18.0 \mu \mathrm{g} / \mathrm{m}^{3}$ to $25.7 \mu \mathrm{g} / \mathrm{m}^{3}$ for industrial area. According to Hussan et al. (2013), fuelling material contributes to higher values of $\mathrm{SO}_{2}$. Limbochiya and Patel (2013) reported higher concentration of $\mathrm{SO}_{2}$ in areas close to industrial establishment. Sharma and Raina (2015) also recorded higher $\mathrm{SO}_{2}$ in areas using diesel generator sets.

The minimum concentration of $\mathrm{SO}_{2}$ is recorded for Site- $\mathrm{V}$ which represents the sensitive area-SMHS Hospital $\left(6.00 \mu \mathrm{g} / \mathrm{m}^{3}\right)$. Minimum values are attributed to the fact that use of fuel and generators sets in the area is less and no industrial setup is located in the vicinity of the area.

Since the study was carried from October to January, the higher values recorded was for January because of calm weather conditions during winter season leading to more stability, slow dispersion of pollutants in the atmosphere and inversion factor causing higher concentration of pollutants in atmosphere. The study of Lakshmanarao and Satish (2014) also reported maximum values during winter season. Panda and Panda (2012) also record relatively higher levels of $\mathrm{SO}_{2}$ during winter in comparison to summer and monsoon. According to Rai and Chutia (2014), air pollutants tend to concentrate in winter season due to high atmospheric stability and inversion factor.

3.3 $P M_{10}$

The $\mathrm{PM}_{10}$ recorded at different sites is given in Figure 1. No significant variation in $\mathrm{PM}_{10}$ was recorded within the sites $\left(\mathrm{F}_{3}=1.90, \mathrm{P}<0.05\right)$ whereas significant variation was recorded among $\left(\mathrm{F}_{4}=72.55, \mathrm{P}<0.05\right)$ the sites. At site I, II, III and IV the minimum concentration of $\mathrm{PM}_{10}$ was found to be $98 \mu \mathrm{g} / \mathrm{m}^{3}, 115.1 \mu \mathrm{g} / \mathrm{m}^{3}, 40 \mu \mathrm{g} / \mathrm{m}^{3}$ and $31 \mu \mathrm{g} / \mathrm{m}^{3}$ in the month of October and maximum to be $111 \mu \mathrm{g} / \mathrm{m}^{3}, 181 \mu \mathrm{g} / \mathrm{m}^{3}, 42.8 \mu \mathrm{g} / \mathrm{m}^{3}$ and $35.5 \mu \mathrm{g} / \mathrm{m}^{3}$ in the month of January respectively. While at site- $\mathrm{V}, \mathrm{PM}_{10}$ exhibited minimum concentration of $39.8 \mu \mathrm{g} / \mathrm{m}^{3}$ in the month of October and $42.3 \mu \mathrm{g} / \mathrm{m}^{3}$ in the month of December. The mean value recorded (Figure 2) was $105.75 \pm 2.87$ (LalChowk), 161.025 \pm 15.53 (khanmoh), 41.475 \pm 0.62 (Rainawari), 33.625 \pm 1.03 (Nehru Park) and $40.8 \pm 0.58$ (SMHS).

$\mathrm{PM}_{10}$ exhibited a range of $31 \mu / \mathrm{m}^{3}$ to $181 \mu / \mathrm{m}^{3}$ among different sites. The maximum concentration was recorded for site-II which represents the Industrial area $\left(181 \mu \mathrm{g} / \mathrm{m}^{3}\right)$ and minimum concentration was recorded for site-IV which represents ecologically sensitive area $\left(31 \mu \mathrm{g} / \mathrm{m}^{3}\right)$. The higher ranges of $\mathrm{PM}_{10}$ in industrial area have key contributions from the cement factories and other industrial processes. High vehicular traffic, increasing number of heavy vehicles, unpaved roads, and resuspension of dust from roads contribute to the high levels of $\mathrm{PM}_{10}$ in the area. Bhaskar and Mehta (2010) reported that particulate pollutant concentration is higher in industrial and traffic areas and less in residential area. According to Lamare and Chaturvedi (2014), elevated $\mathrm{PM}_{10}$ concentrations are attributed mainly to increasing number of vehicles. Limbochiya and Patel (2013) also reported higher concentration of particulate in and around industrial areas. According to Meenambai and Akil (2000), higher values of $\mathrm{PM}_{10}$ are due to traffic congestion and increased human activity such as construction. Bhuyan et al. (2014) also revealed that the traffic system, road construction, burning of municipal wastes and unpaved roads are the main cause of higher levels of particulate matter $\left(\mathrm{PM}_{10}\right)$.

The national ambient air quality standards (NAAQS), 2009 of Central Pollution Control Board (CPCB) is given in Table 2. From the table it is clear that the concentration of different pollutants at different sites falls within the permissible limits except for the $\mathrm{PM}_{10}$ at site-II (Khanmoh) followed by Site-I (Lalchowk). The site-II being the industrial area with cement factories could be the reason for the higher $\mathrm{PM}_{10}$ whereas the Site-I which is having higher vehicular load results in higher concentration of $\mathrm{PM}_{10}$. 
Table 2. Comparison of observed concentration of different pollutants at different sites with National Ambient Air Quality Standard (NAAQS), 2009

\begin{tabular}{ccccccccc}
\hline \multicolumn{1}{c}{ Observed concentrations at different sites } & \multicolumn{3}{c}{ Prescribed limits } \\
\hline Pollutant & Site-I & Site-II & Site-III & Site-IV & Site-V & $\begin{array}{c}\text { Weighted } \\
\text { Average }\end{array}$ & $\begin{array}{c}\text { Rural and } \\
\text { other areas }\end{array}$ & $\begin{array}{c}\text { Sensitive } \\
\text { area } \\
\text { Annual 24 }\end{array}$ \\
$\begin{array}{c}\text { Sulphur Dioxide } \\
\left(\mu \mathrm{g} / \mathrm{m}^{3}\right)\end{array}$ & 13.49 & 19.77 & 8.19 & 7.26 & 7.53 & $\begin{array}{c}\text { Hours } \\
20\end{array}$ & 80 & 80 \\
$\begin{array}{c}\text { Nitrogen Dioxide } \\
\left(\mu \mathrm{g} / \mathrm{m}^{3}\right)\end{array}$ & 18.54 & 17.17 & 14.25 & 10.46 & 10.35 & Annual 24 & 40 & 30 \\
$\begin{array}{c}\text { Particulate Matter } \\
(<10 \mu \mathrm{m}) \mu \mathrm{g} / \mathrm{m}^{3}\end{array}$ & 105.75 & 161.02 & 41.47 & 33.62 & 40.8 & Annual 24 & 60 & 60 \\
\hline
\end{tabular}

\subsection{Air Quality Index (AQI)}

The air quality index (AQI) of different pollutants at different sites based on the concentration in Table 3 . For site-I, the air quality index for $\mathrm{PM}_{10}, \mathrm{SO}_{2}$ and $\mathrm{NO}_{2}$ is $104.14,16.68$, and 23.16 respectively. At site-II, AQI for $\mathrm{PM}_{10}$ is $140.62, \mathrm{SO}_{2}$ is 24.71 and $\mathrm{NO}_{2}$ is 21.46 . For site-III, $\mathrm{PM}_{10}, \mathrm{SO}_{2}$ and $\mathrm{NO}_{2}$ exhibited values of 41.48, 10.24 and 17.81 respectively. For site-IV, the value of $\mathrm{PM}_{10}$ is $33.63, \mathrm{SO}_{2}$ is 9.075 and $\mathrm{NO}_{2}$ is 13.08 . For site- $\mathrm{V}$, the value is 40.8, 9.41 and12.04 for $\mathrm{PM}_{10}, \mathrm{SO}_{2}$ and $\mathrm{NO}_{2}$ respectively. The percent contribution of pollutant at different sites is given in Figure 3.
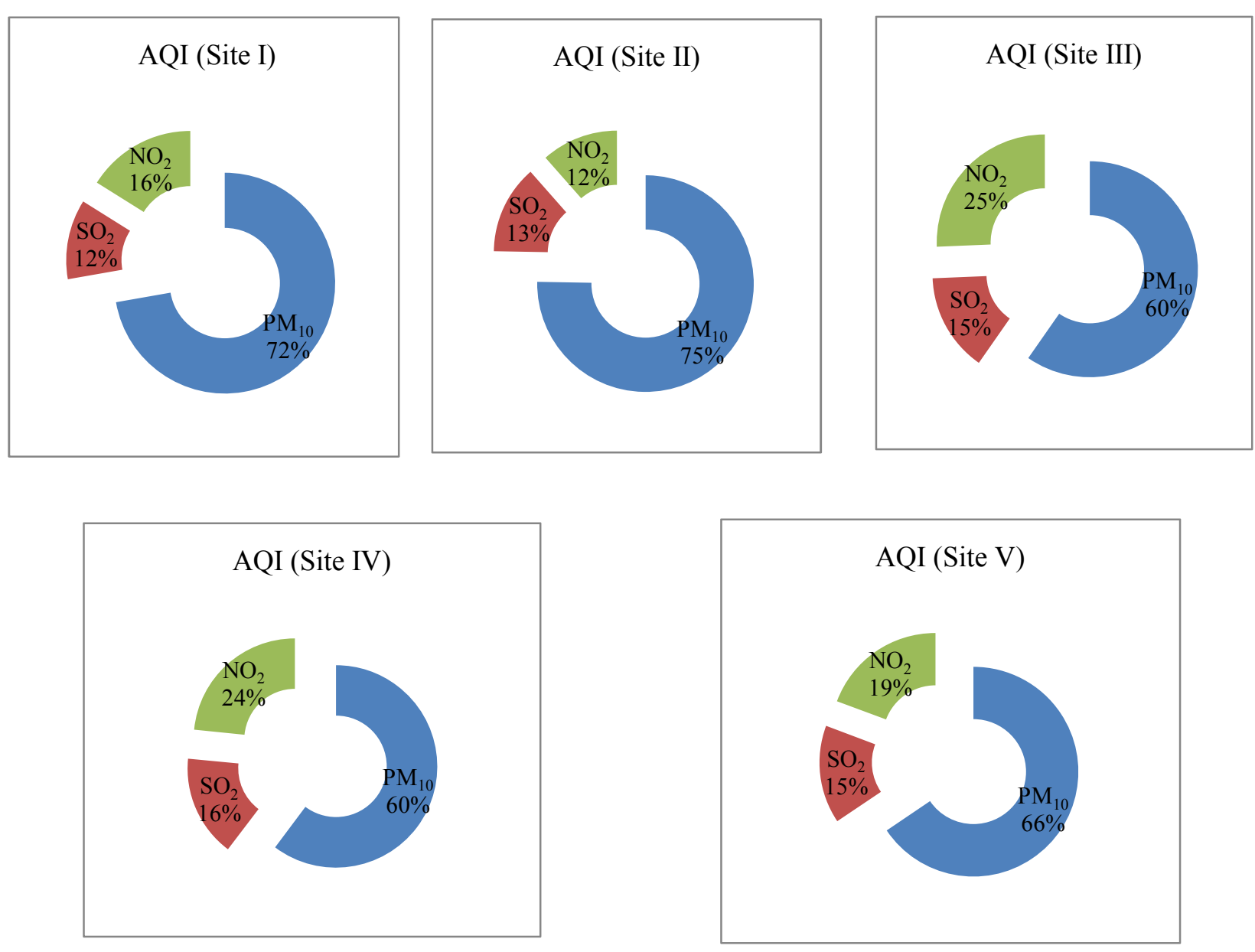

Figure 3. Air quality Index (AQI) of different pollutants at different sites and their percent contribution 
Table 3. Calculated air quality index (AQI) of different pollutants at different sites and overall air quality index of each site based on the color coding system of Indian standard (CPCB)

\begin{tabular}{lccccc}
\multirow{2}{*}{ Sites } & \multicolumn{3}{c}{ Pollutant with their AQI } & Overall & Overall \\
\cline { 2 - 4 } & $\mathbf{P M}_{\mathbf{1 0}}$ & $\mathbf{S O}_{\mathbf{2}}$ & $\mathbf{N O}_{\mathbf{2}}$ & AQI & Category \\
\hline Site-I & 104.14 & 16.86 & 23.16 & 104.13 & Moderate \\
Site-II & 140.62 & 24.71 & 21.46 & 140.62 & Moderate \\
Site-III & 41.48 & 10.24 & 17.81 & 41.48 & Good \\
Site-IV & 33.63 & 9.075 & 13.08 & 33.63 & Good \\
Site-V & 40.8 & 9.41 & 12.04 & 40.8 & Good \\
\hline
\end{tabular}

The Table for air quality index with range and color coding as per Central Pollution Control Board (2014) is given in Table 4 and its associated health statements in Table 5. From the table it is clear that the air quality index of all sites based on their respective concentration of $\mathrm{PM}_{10}, \mathrm{SO}_{2}$ and $\mathrm{NO}_{2}$ showed varied index. For $\mathrm{SO}_{2}$ and $\mathrm{NO}_{2}$, the air quality falls within "Good" air quality index category for all sites except for the $\mathrm{PM}_{10}$, the index falls within the "Moderate" category for site-I and site-II and whereas for site III, IV and V the index falls within "Good" air quality index category. Since the air quality index values of $\mathrm{PM}_{10}$ are higher than the air quality index values for $\mathrm{SO}_{2}$ and $\mathrm{NO}_{2}$, thus $\mathrm{PM}_{10}$ determines the overall air quality index of all sites (Figure 3). Thus, the air quality of site-I and site-II is "Moderate" and site III, IV and V has "Good" air quality according to India Air quality Index (IND-AQI). Thus it is clear that the air quality of site-I and Site-II is unhealthy for sensitive group and may cause breathing discomfort to the people with lung disease such as asthma and discomfort to people with heart disease, children and older adults (Table 5).

Table 4. Air quality index (AQI) system with range, categories and color coding as per CPCB, 2014

\begin{tabular}{lcccccccc}
\hline $\begin{array}{l}\text { AQI Category } \\
\text { (Range) }\end{array}$ & $\mathrm{PM}_{10}$ & $\mathrm{PM}_{2.5}$ & $\mathrm{NO}_{2}$ & $\mathrm{O}_{3}$ & $\mathrm{CO}$ & $\mathrm{SO}_{2}$ & $\mathrm{NH}_{3}$ & $\mathrm{~Pb}$ \\
\hline Good (0-50) & $24-\mathrm{hr}$ & $24-\mathrm{hr}$ & $24-\mathrm{hr}$ & $8-\mathrm{hr}$ & $8-\mathrm{hr}\left(\mathrm{mg} / \mathrm{m}^{3}\right)$ & $24-\mathrm{hr}$ & $24-\mathrm{hr}$ & $24-\mathrm{hr}$ \\
\hline Satisfactory (51-100) & $51-100$ & $0-30$ & $0-40$ & $0-50$ & $0-1.0$ & $0-40$ & $0-200$ & $0-0.5$ \\
Moderate (101-200) & $101-250$ & $61-90$ & $41-80$ & $51-100$ & $1.1-2.0$ & $41-80$ & $201-400$ & $0.6-1.0$ \\
Poor (201-300) & $151-350$ & $91-120$ & $181-280$ & $169-208$ & $10.1-17$ & $381-800$ & $801-1200$ & $2.1-3.0$ \\
Very poor (301-400) & $351-430$ & $121-250$ & $281-400$ & $209-748$ & $17.1-34$ & $801-1600$ & $1201-1800$ & $3.1-3.5$ \\
Severe (401-500) & $430+$ & $250+$ & $400+$ & $748+$ & $34+$ & $1600+$ & $1800+$ & $3.5+$ \\
\hline
\end{tabular}

Table 5. Health statements for AQI Categories as per CPCB, 2014

\begin{tabular}{lr}
\hline AQI & \multicolumn{1}{c}{$\begin{array}{c}\text { Associated Health Impacts } \\
\text { Good (0-50) }\end{array}$} \\
$\begin{array}{l}\text { Satisfactory (51-100) } \\
\text { Moderate (101-200) }\end{array}$ & $\begin{array}{r}\text { May cause breathing discomfort to the people with lung disease such as asthma and } \\
\text { discomfort to people with heart disease, children and older adults }\end{array}$ \\
Poor (201-300) & $\begin{array}{r}\text { May cause breathing discomfort to people on prolonged exposure and discomfort to } \\
\text { people with heart disease with short exposure }\end{array}$ \\
Very Poor (301-400) & $\begin{array}{r}\text { May cause respiratory illness to the people on prolonged exposure. Effect may be more } \\
\text { pronounced in people with lung and heart diseases }\end{array}$ \\
Severe (401-500) & $\begin{array}{r}\text { May cause respiratory effects even on healthy people and serious health impacts on } \\
\text { people with lung/heart diseases. The health impacts may be experienced even during } \\
\text { light physical activity }\end{array}$
\end{tabular}


Neelima et al. (2014) also reported $\mathrm{SO}_{2}$ and $\mathrm{NO}_{2}$ concentration and their respective value of AQI within "Good" and "good to moderate" while for $\mathrm{PM}_{10}$ and SPM as "Unhealthy to Very poor" category. Panda and Panda (2012) reported that high values of AQI are mainly due to SPM and RSPM. According to Mamta and Bassin (2010), suspended particulate matter (SPM) is mainly responsible for higher values among different pollutants and determined the overall AQI category of "Very poor". Sharma and Raina (2013) and Goyal (2001) also reported SPM as the dominant pollutant determining the overall air quality index.

\section{Conclusions}

The present study revealed that the concentration of $\mathrm{NO}_{2}$ was found to be higher in commercial area and is contributed to vehicular emission and the area being highly urbanized. $\mathrm{SO}_{2}$ concentration was found to be higher in industrial area due to burning of fuels in industrial units and use of diesel generator. $\mathrm{PM}_{10}$ exhibited higher values in industrial area due the presence of cement industries and burning of coal as fuel in different industrial units, in addition to the poorly maintained roads and heavy vehicular movement. However, the overall concentration of different pollutants $\left(\mathrm{SO}_{2}\right.$ and $\left.\mathrm{NO}_{2}\right)$ was within the permissible limits of National Ambient air Quality standards (NAAQS) at all sites except for particulate matter $\left(\mathrm{PM}_{10}\right)$ at site-I and site-II. The overall concentration of all the pollutants was found higher in the month of January because of calm weather conditions and stagnant air leading to more stability and slow dispersion of pollutants within the atmosphere. The air quality index (AQI) was contributed by $\mathrm{PM}_{10}$ because of higher value of $\mathrm{PM}_{10}$ at all sites. The Air quality index of commercial and industrial site falls within "Moderate" category and for residential and ecologically sensitive site it falls within "Good" category.

\section{References}

Aneja, V. P., Agarwal, A., Roelle P. A., Phillips, S. B., Tong, Q., Watkins, N., \& Yablonsky, R. (2001). Measurement and analysis of criteria pollutants in New Delhi, India. Environment International, 27, 35-42. https://doi.org/10.1016/S0160-4120(01)00051-4

Banerjee, T., \& Srivastava, R. K. (2010). Assessment of ambient air quality at the Integrated Industrial Estate-Pantnagar through the Air Quality Index and Exceedence factor (EF). Asia Pacific Journal of chemical Engineering, 6, 64-70. https://doi.org/10.1002/apj.450

Barman, S. C., Kumar, N., Singh, R., Kishu, G. S., Khan, A. H., Kidwai, M. M., ... Bhargava, S. K. (2010). Assessment of urban air pollution and its probable health impact. Journal of Environmental Biology, 31(6), 913-920.

Bhaskar, B. V., \& Mehta, V. M. (2010). Armospheric particulate pollutants and their relationship with meteorology in Ahmedabad. Aerosol and Air Quality Research, 10, 301-315.

Bhuyan, G., Anandhan, R., \& Kavitha, V. (2014). Measurement of statistical analysis of ambient air quality status in Cuddadore region, Tamilnadu, India. Journal of Biological and Scientific Opinion, 2(2), 177-180. https://doi.org/10.7897/2321-6328.02240

Dadhich, A. P., Goyal, R., \& Dadhich, P. N. (2017). Assessment of spatio-temporal variations in air quality of Jaipur city, Rajasthan, India. Egypt. Journal of Remote Sensing Space Sci. https://doi.org/10.1016/j.ejrs.2017.04.002

Emberson, L. D., Ashmore, M. R., Murray, F., Kuylenstierna, J. C. I., Percy, K. E., Izuta, T., ... Domingos, M. (2001). Impacts of air pollutants on vegetation in developing countries. Water Air Soil Pollution, 130, 107-118. https://doi.org/10.1023/A:1012251503358

Goyal, P. (2001). Flexibility in estimating air quality index: A case study of Delhi. Global Journal of Flexible System Management, 2, 39-44.

Grundström, M., \& Pleijel, H. (2014). Limited effect of urban tree vegetation on $\mathrm{NO}_{2}$ and $\mathrm{O}_{3}$ concentrations near a traffic route. Environmental Pollution, 189, 73-76. https://doi.org/10.1016/j.envpol.2014.02.026

Hussan, A., Bhat, G. A., \& Sheikh, M. A. (2013). Impact of Brick Kilns and vehicular emissions on Lichen diversity in Khanabal area of Anantnag District (J\&K), India. International Research Journal of Environment Sciences, 2(4), 30-33.

Ishtiyaq, A. N., Anisa, B. K., \& Abdul, H. (2017). Evaluation of seasonal variability in surface water quality of Anchar Lake, Kashmir, India, using multivariate statistical techniques. Pollution, 3(3), 349-362.

Jacobs, M. B., \& Hochheiser, S. (1958). Continuous sampling and ultra-micro determination of nitrogen dioxide in air. Anal of Chemistry, 30, 426. https://doi.org/10.1021/ac60135a032 
Kishore, N., \& Deswal, S. (2017). Analysis of air pollution in Indian cities - A Literature Review. International Journal on Emerging Technologies, 8(1), 191-195.

Lakshmanarao, V., \& Satish, P. (2014). Management of air quality in coastal environments. Journal of International Academic Research for Multidisciplinary, 2(3), 174-184.

Lamre, R. E., \& Chaturvedi, S. S. (2014). Suspended particulate matter in ambient air of Shillong city, Meghalaya, India. Journal of Science, Research and Technology, 2(6), 37-41.

Limbochiya, S., \& Patel, R. S. (2013). Air pollution in urban Ahmedabad, Gujarat, India. International Monthly Referred Journal of Research in Management and Technology, 2, 30-35.

Loomis, D., Huang, W., \& Chen, G. (2014). The International Agency for Research on Cancer (IARC) evaluation of the carcinogenicity of outdoor air pollution: focus on China. Chinese Journal of Cancer, 33(4), 189-196. https://doi.org/10.5732/cjc.014.10028

Mamta, P., \& Bassin, J. K. (2010). Analysis of ambient air quality using air quality index- a case study (2010). International Journal of Advanced Engineering Technology, 1(2), 106-114.

Mandal, S. (2000). Progressive decrease of air pollution level from West to East Calcutta, Indian. Journal of Environmental Protection, 20, 6-10.

Meenakshi, P., \& Saseetharan, M. K. (2004). Urban Air Pollution Forecasting with Respect to SPM using Time Series Neural Networks Modelling Approach- A Case Study in Coimbatore City. Journal of Environmental Science and Engineering, 46, 92-101.

Meenambai, T., \& Akil, K. (2000). Ambient air quality at selected sites in Coimbatore city. Indian Journal of Environmental Protection, 20, 49-53.

Memon, E. (2000). Environmental effects of thermal power plant emissions- A case study. Canada: Faculty of Engineering and Applied Science, Memorial University of Newfoundland.

Najar, I. A., \& Khan, A. B. (2013). Effect of vermicompost on growth and productivity of tomato (Lycopersicon esculentum) under field conditions. Acta Biologica Malaysiana, 2(1), 12-21.

Najar, I. A., \& Khan, A. B. (2011). Earthworm communities of Kashmir Valley, J\&K, India. Tropical Ecology, 52(2), 151-162.

Najar, I. A., \& Khan, A. B. (2012). Assessment of water quality and identification of pollution sources of three lakes in Kashmir, India, using multivariate analysis. Environmental Earth Sciences, 66(8), 2367-2378. https://doi.org/10.1007/s12665-011-1458-1

Najar, I. A., \& Khan, A. B. (2014). Factors Affecting Distribution of Earthworms in Kashmir Valley: A Multivariate Statistical Approach. Proceedings of the Zoological Society, 67(2), 126-135. https://doi.org/10.1007/s12595-013-0081-4

Najar, I. A., Khan, A. B., \& Hai, A. (2015). Effect of macrophyte vermicompost on growth and productivity of brinjal (Solanum melongena) under field conditions. International Journal of Recycling of Organic Waste in Agriculture, 4(2), 73-83. https://doi.org/10.1007/s40093-015-0087-1

Neelima, N., Bamniya, B. R., Mahecha, G. S., \& Dhavan, S. (2014). Analysis of ambient air pollution and determination of air quality status of Udaipur, Rajasthan, India. International Journal of Environment Sciences, 3(6), 5-10.

Ott, W. R. (1978). Environmental indices theory and practice. Ann Arbor Science Publishers Inc.

Panda, B. K., \& Panda, C. R. (2012). Estimation of ambient air quality status in Kalinga Nagar industrial complex in the district of Jajpur of Odhisa. International Journal of Environmental Sciences, 3(2), 767-775.

Rai, P. K., \& Chutia, B. M. (2014). Assessment of Ambient air quality status before and after shifting cultivation in an Indo-Burma hotspot region. International Research Journal of Environment Sciences, 3(11), 1-5.

Saksena, S., Singh, P. B., Kumar, P. R., Rakesh, P., Malhotra, P., Joshi, V., \& Patil, R. S. (2003). Exposure of infants to outdoor and indoor air pollution in low-income Urban areas - a case study of Delhi. Journal of Exposure Analysis and Environmental Epidemiology, 13, 219-230. https://doi.org/10.1038/sj.jea.7500273

Sarangi, P. K., \& Mishra, P. C. (1997). Ambient air quality of Jyotivihar, Orissa. India Pollution Research, 16, 33-35.

Sharma, A., \& Raina, A. K. (2013). Assessment of the status of SPM in Jammu City and its control strategies. 
IOSR Journal of Environmental Science, Toxicology and Food Technology, 7(1), 8-12. https://doi.org/10.9790/2402-0710812

Sharma, A., \& Raina, A. K. (2015). Ambient air quality of Katra town (J\&K): A study with reference to $\mathrm{SO}_{2}$ and $\mathrm{NO}_{2}$ contents. International Journal of Environmental Sciences, 6(1), 46-55.

Swami, P. K., \& Tyagi, A. (1999). Formation of an air pollution index. Journal of Air and Waste Management Association, 49, 88-91. https://doi.org/10.1080/10473289.1999.10463776

Taieb, D., \& Brahim, A. B. (2013). Methodology for developing an air quality index (AQI) for Tunisia. International Journal of Renewable Energy Technology, 4(1), 86-106. https://doi.org/10.1504/IJRET.2013.051067

Wellburn, A. (1998). Sulfur Dioxide In: Air Pollution and Acid rain: The Biological Impact. Longman Scientific \& Technical, John Wiley and Sons, 23-59.

West, P. W., \& Gaeke, G. C. (1956). Fixation of sulfur dioxide as disulntomercurate (II) and subsequent colorimetric estimation. Anal of Chemistry, 28, 1816-1819. https://doi.org/10.1021/ac60120a005

\section{Copyrights}

Copyright for this article is retained by the author(s), with first publication rights granted to the journal.

This is an open-access article distributed under the terms and conditions of the Creative Commons Attribution license (http://creativecommons.org/licenses/by/4.0/). 